\title{
EFFECT OF PROLONGED INGESTION OF POLYCHLORINATED BIPHENYLS ON THE RAT
}

\author{
J. V. Bruckner, K. L. Khanna and H. H. Cornish \\ The University of Michigan, Department of Environmental and Industrial Health, School of \\ Public Health. Am Arbor. Michigan 48104. USA
}

(Received 14 December 1973)

\begin{abstract}
Aroclor 1242, a commercial polychlorinated biphenyl mixture, was fed to rats at dietary levels of 0,5 and $25 \mathrm{ppm}$ for 2, 4 and 6 months. Significant elevations of urinary coproporphyrin excretion, hepatic lipid and hepatic microsomal-hydroxylase activity were observed in rats ingesting $25 \mathrm{ppm}$ for 2 months. In rats given the 5 or $25 \mathrm{ppm}$ regimens for 4 or 6 months, urinary coproporphyrin excretion and liver weight, lipid content and microsomal-hydroxylase activity were higher than in controls. Histopathological examination revealed lipid vacuolation and proliferation of smooth endoplasmic reticulum in the hepatocytes of treated animals. These findings indicate that long-term, low-level ingestion of Aroclor 1242 may result in changes in a variety of biological parameters.
\end{abstract}

\section{INTRODUCTION}

Polychlorinated biphenyls (PCBs), a series of chlorinated polycyclic hydrocarbons, have become the subject of widespread concern in recent years. Commercial PCB products consist of mixtures of isomers, differing from one another in degree of chlorination. As PCBs are water-insoluble and inert, they have been used extensively as surface coatings, flame retardants, stabilizers, capacitors, heat-transfer agents and components of plasticizers, adhesives and printing inks. Such industrial applications have apparently resulted in world-wide environmental contamination (Nisbet \& Sarofim, 1972) and accumulation in the tissues of many biological species (Risebrough \& de Lappe, 1972).

Investigations have demonstrated the presence of PCBs in human foodstuffs and adipose tissue. Price $\&$ Welch (1972) found that $41-45 \%$ of human adipose samples, obtained from the general population of the United States, contained $>1.0 \mathrm{ppm}$ PCBs. Potential dietary sources of PCBs include fish, poultry, milk, eggs and cereals (Kolbye, 1972). The FDA interim guideline for PCB contamination of human foodstuffs has been set at $5 \mathrm{ppm}$, with lower levels recommended for long-term ingestion.

Though current environmental and dietary levels of PCBs are not felt to constitute an immediate health hazard, limited information is available concerning biological manifestations of long-term, low-level exposure in mammals. Kimbrough, Linder \& Gaines (1972) reported significant increases in liver to body-weight ratios in rats fed 5 ppm Aroclor 1254 or Aroclor 1260 for 8 months. These same commercial PCB products at dietary levels as low as 0.5 and $5 \mathrm{ppm}$ may induce certain hepatic microsomal-enzyme activities in rats within 4 wk (Litterst, Farber, Baker \& Van Loon, 1972). A 1-yr 20 ppm dietary regimen of Aroclors 1242, 1254 or 1260 has been reported to reduce pentobarbitone sleeping time in rats (Villeneuve, Grant \& Phillips, 1972). 
The present study was initiated to elucidate biological responses in the rat upon prolonged ingestion of a common PCB product, Aroclor 1242. Dosage levels corresponding to the contemporary FDA guideline and to a level encountered in fish were selected. Emphasis was placed upon biological parameters shown to be altered by acute and subacute dosage regimens in previous investigations (Bruckner, Khanna \& Cornish. 1973 \& 1974).

\section{EXPERIMENTAL}

Animals: Male Sprague Dawley rats (mean body weight $125 \mathrm{~g}$ ) were obtained from Spartan Research Farm, Lansing. Mich. The rats were randomly divided into groups of six animals and housed in pairs in stainless-steel cages in air-conditioned quarters, with tap-water and ground Rockland rat and mouse chow available ad lib. Only during collection of urine specimens were the rats confined individually in metabolism cages.

Materials and dosage. Aroclor 1242 (lot no. KA 419) was supplied by Monsanto Chemical Company, St. Louis, Mo. Appropriate quantities of Aroclor 1242 were dissolved in acetone and mixed thoroughly with a small amount of ground chow. After the acetone had been allowed to evaporate, the Aroclor-chow mixture was mixed by geometric dilution with increasing amounts of chow until desired Aroclor 1242 concentrations of 5 and $25 \mathrm{ppm}$ were attained. The groups of six rats were fed the diets containing 0,5 or $25 \mathrm{ppm}$ Aroclor 1242 for 2, 4 or 6 months. Body weights and food consumption were measured at weekly intervals.

Urine analysis. Urinary excretion of coproporphyrin was determined by the method of Schwartz, Zieve \& Watson (1951) 1 wk before the rats were killed.

Haematology. At the end of the treatment period, blood samples were taken from tail veins for determinations of haematocrit, erythrocyte counts and haemoglobin levels. Erythrocyte counts, utilizing a Coulter counter, were performed for the 6-month groups only. Haemoglobin levels were measured by a technique involving cyanmethaemoglobin formation (Davidsohn \& Henry, 1969). Following anaesthetization with ether, blood was withdrawn by open-chest cardiac puncture. Serum glutamic-pyruvic transaminase (SGPT) and serum glutamic-oxalacetic transaminase (SGOT) activities were determined by standard procedures. The method of Solem \& Brinck-Johnsen (1965) was used for analysis of plasma corticosteroids.

Microsomal-enzyme assays. Hydroxylase activity was estimated in the $13,000 \mathrm{~g}$ supernatant of $5 \mathrm{~g}$ liver samples by measurement of $N$-acetyl-p-aminophenol formation from acetanilide, and $N$-demethylase activity by measurement of 4 -aminoantipyrine formation from aminopyrine. Methods utilized were outlined in a previous investigation (Bruckner ('t al. 1973).

Hepatic studies. Liver weights were recorded and total liver lipid was assayed by the procedure of Bligh \& Dyer (1959).

Histopathology. Liver and kidney specimens were processed and stained with haematoxylin and eosin for light microscopic examination. Frozen sections of liver and kidney were stained for fat with Sudan IV. Cubes of liver were minced and fixed in cold $3 \%$ phosphatebuffered glutaraldehyde for $2 \mathrm{hr}$, stained in $2 \%$ osmium tetroxide for $2 \mathrm{hr}$, dehydrated in an ethanol and propylene oxide series and embedded in Epon plastic. Sections were poststained with uranyl acetate and lead citrate and examined with an AEI Cornith 275 electron microscope.

Statistical analysis. The significance of all results was assessed by Student's $t$ test. 


\section{RESULTS}

Body weight and food consumption

No significant differences in body-weight gain were seen at any dietary level after 2.4 or 6 months. Food consumption was comparable at each dietary level throughout the course of the study. With the average food intake of $25 \mathrm{~g} / \mathrm{rat} /$ day, the $5 \mathrm{ppm}$ groups ingested approximately $0.3 \mathrm{mg}$ Aroclor $1242 / \mathrm{kg}$ body weight/day, the $25 \mathrm{ppm}$ groups approximately $1.5 \mathrm{mg}$ Aroclor $1242 / \mathrm{kg} /$ day. Total Aroclor 1242 consumption during the course of the studies is expressed in Table 1.

Table 1. Approximate total consumption of Aroclor 1242 by test groups

\begin{tabular}{|c|c|c|c|}
\hline \multirow[b]{2}{*}{$\begin{array}{l}\text { Dose } \\
(\mathrm{ppm})\end{array}$} & \multicolumn{3}{|c|}{$\begin{array}{l}\text { Total Aroclor } 1242 \text { consumption* (mg/rat) during test period of } \\
\text { (months) }\end{array}$} \\
\hline & 2 & 4 & 6 \\
\hline 5 & 7 & 14 & 21 \\
\hline 25 & 35 & 70 & 105 \\
\hline
\end{tabular}

\section{Haematology}

Results of blood assays other than SGOT, SGPT and plasma corticosteroid determinations are given in Table 2. No significant alterations in SGOT, SGPT or plasma corticosteroid levels were seen at any dietary level after 2, 4 or 6 months. Only in the group fed $25 \mathrm{ppm}$ Aroclor 1242 for 2 months were significant reductions in haematocrit recorded. A significant reduction in haemoglobin levels occurred in the groups fed 5 or $25 \mathrm{ppm}$ for 2 months. Slight reductions from control values in haematocrit and erythrocyte count were noted in the group given $25 \mathrm{ppm}$ for 6 months, although mean values were not statistically different from those of the controls.

Table 2. Effect of prolonged, low-level ingestion of Aroclor 1242 on haematocrit, erythrocyte count and haemoglobin level

\begin{tabular}{|c|c|c|c|c|}
\hline $\begin{array}{l}\text { Duration } \\
\text { of test } \\
\text { (months) }\end{array}$ & $\begin{array}{c}\text { Dose } \\
(\mathrm{ppm})\end{array}$ & $\begin{array}{c}\text { Haematocrit } \dagger \\
(0)\end{array}$ & $\begin{array}{c}\text { Erythrocyte } \\
\text { count } \\
\left(10^{6} / \mathrm{mm}^{3}\right)\end{array}$ & $\begin{array}{l}\text { Haemoglobin } \\
(\mathrm{g} / 100 \mathrm{ml})\end{array}$ \\
\hline 2 & $\begin{array}{l}0 \\
5 \\
25\end{array}$ & $\begin{array}{l}51 \cdot 0 \pm 1 \cdot 0 \\
50 \cdot 6 \pm 0 \cdot 6 \\
48 \cdot 0 \pm 0 \cdot 6^{*}\end{array}$ & & $\begin{array}{l}16 \cdot 1 \pm 0 \cdot 1 \\
15 \cdot 1 \pm 0 \cdot 1^{*} \\
14.8 \pm 0.2^{* *}\end{array}$ \\
\hline 4 & $\begin{array}{l}0 \\
5 \\
25\end{array}$ & $\begin{array}{l}52 \cdot 6 \pm 1 \cdot 3 \\
51 \cdot 7 \pm 0.9 \\
53.2 \pm 0.9\end{array}$ & & $\begin{array}{l}17 \cdot 1 \pm 0 \cdot 3 \\
16 \cdot 2 \pm 0 \cdot 4 \\
16 \cdot 8 \pm 0.3\end{array}$ \\
\hline 6 & $\begin{array}{l}0 \\
5 \\
25\end{array}$ & $\begin{array}{l}55 \cdot 2 \pm 1 \cdot 3 \\
56 \cdot 0 \pm 0 \cdot 2 \\
54 \cdot 0 \pm 1 \cdot 1\end{array}$ & $\begin{array}{r}10 \cdot 3 \pm 0 \cdot 4 \\
10 \cdot 1 \pm 0 \cdot 3 \\
9 \cdot 7 \pm 0 \cdot 1\end{array}$ & $\begin{array}{l}16 \cdot 8 \pm 0 \cdot 4 \\
16.2 \pm 0 \cdot 4 \\
15 \cdot 9 \pm 0 \cdot 5\end{array}$ \\
\hline
\end{tabular}

tMean values represent an average of two determinations/rat.

Values are means \pm SEM for groups of six rats and those marked with asterisks differ significantly (Student's $t$ test) from the control values: ${ }^{*} P<0.01:{ }^{* *} P<0.001$. 
Microsomal-enzyme assays

Table 3 presents the effects of the dietary regimens on the activities of hepatic microsomal hydroxylase and $N$-demethylase. A significant induction of hydroxylase activity was manifest in rats that had consumed 25 ppm Aroclor 1242 for 2 months. Hydroxylase activity was induced in some members of the group given 5 ppm for 2 months but not in others. Dose-dependent increases in hydroxylase activity were measured at each sampling period. The $5 \mathrm{ppm}$ diet did not alter $N$-demethylase activity significantly at any sampling period, though the $25 \mathrm{ppm}$ diet induced significant increases in the 4 -and 6-month groups.

Table 3. Effect of prolonged. Ion-lewel ingestion of Arodor 1242 on hepatic microsonal hydroxylase and N-demethylase activitics

\begin{tabular}{|c|c|c|c|c|c|}
\hline \multirow[b]{2}{*}{$\begin{array}{l}\text { Duration } \\
\text { of test } \\
\text { (months) }\end{array}$} & \multirow[b]{2}{*}{$\begin{array}{c}\text { Dose } \\
\text { (ppm) }\end{array}$} & \multicolumn{2}{|c|}{ Hydroxylase activity } & \multicolumn{2}{|c|}{$N$-Demethylase activity } \\
\hline & & $\begin{array}{l}N \text {-Acetyl-p-aminophenol } \\
\text { formed } \\
(\mu \mathrm{g} / \mathrm{mg} \text { protein } / 20 \mathrm{~min})\end{array}$ & $\begin{array}{l}\text { of of } \\
\text { control } \\
\text { value }\end{array}$ & $\begin{array}{c}\text { 4-Aminoantipyrine } \\
\text { formed } \\
(\mu \mathrm{g} / \mathrm{mg} \text { protein } 20 \mathrm{~min})\end{array}$ & $\begin{array}{l}\text { a of } \\
\text { control } \\
\text { value }\end{array}$ \\
\hline 2 & $\begin{array}{l}0 \\
5 \\
25\end{array}$ & $\begin{array}{l}0 \cdot 14 \pm 0.01 \\
0 \cdot 19 \pm 0.02^{*} \\
0.53 \pm 0.04^{* * *}\end{array}$ & $\begin{array}{l}100 \\
140 \\
376\end{array}$ & $\begin{array}{l}0.13 \pm 0.01 \\
0.13 \pm 0.02 \\
0.17 \pm 0.02\end{array}$ & $\begin{array}{l}100 \\
100 \\
133\end{array}$ \\
\hline 4 & $\begin{array}{l}0 \\
5 \\
25\end{array}$ & $\begin{array}{l}0.31 \pm 0.03 \\
0.51 \pm 0.03^{* * *} \\
1 \cdot 06 \pm 0.03^{* * * *}\end{array}$ & $\begin{array}{l}100 \\
163 \\
342\end{array}$ & $\begin{array}{l}0.30 \pm 0.05 \\
0.36 \pm 0.07 \\
0.59 \pm 0.04^{* * *}\end{array}$ & $\begin{array}{l}100 \\
123 \\
197\end{array}$ \\
\hline 6 & $\begin{array}{l}0 \\
5 \\
25\end{array}$ & $\begin{array}{l}0.34 \pm 0.08 \\
0.51 \pm 0.03^{* *} \\
1.38 \pm 0.06^{* * * *}\end{array}$ & $\begin{array}{l}100 \\
147 \\
401\end{array}$ & $\begin{array}{l}0.49 \pm 0.00 \\
0.45 \pm 0.03 \\
0.88 \pm 0.03^{* * * *}\end{array}$ & $\begin{array}{l}100 \\
93 \\
181\end{array}$ \\
\hline
\end{tabular}

Results are expressed as the mean \pm SEM for groups of six rats and as a percentage of the control value. Values marked with asterisks differ ignificantly (Student's, kest) from those for controls: $* P<0) 1$ * ** $P<0.05$ : $* * * P<0 \cdot 01: * * * * P<0.001$.

\section{Urine analysis}

The effect of repeated low-level exposure to Aroclor 1242 on urinary coproporphyrin excretion is summarized in Table 4. A significant rise in coproporphyrin excretion was

Table 4. Effect of prolonged low-level ingestion of Aroclor 1242 on urinary coproporphyth, lines weight and liver lipids

\begin{tabular}{ccccc}
$\begin{array}{c}\text { Duration } \\
\text { of test } \\
\text { (months) }\end{array}$ & $\begin{array}{c}\text { Dose } \\
(\mathrm{ppm})\end{array}$ & $\begin{array}{c}\text { Urinary } \\
\text { coproporphyrin } \\
(\mu \mathrm{g} / 24 \mathrm{hr})\end{array}$ & $\begin{array}{c}\text { Liver weight } \\
(\mathrm{g} / 100 \mathrm{~g} \\
\text { body weight }\end{array}$ & $\begin{array}{c}\text { Total lipids } \\
\text { (mg/g liver } \\
\text { wet wt) }\end{array}$ \\
\hline 2 & 0 & $4 \cdot 7 \pm 0 \cdot 3$ & $3 \cdot 7 \pm 0 \cdot 2$ & $31 \cdot 2 \pm 0 \cdot 7$ \\
& 5 & $5 \cdot 8 \pm 0 \cdot 4^{*}$ & $3 \cdot 6 \pm 0 \cdot 2$ & $35 \cdot 3 \pm 1 \cdot 1^{* * *}$ \\
4 & 25 & $9 \cdot 9 \pm 0 \cdot 6^{* * * *}$ & $3 \cdot 8 \pm 0 \cdot 1$ & $38 \cdot 2 \pm 1 \cdot 0^{* * * *}$ \\
& 0 & $5 \cdot 9 \pm 0 \cdot 9$ & $2 \cdot 9 \pm 0 \cdot 1$ & $33 \cdot 4 \pm 2 \cdot 0$ \\
& 5 & $8 \cdot 5 \pm 1 \cdot 4^{*}$ & $3 \cdot 1 \pm 0 \cdot 1^{*}$ & $40 \cdot 0 \pm 2 \cdot 1^{* *}$ \\
6 & 25 & $16 \cdot 6 \pm 4 \cdot 4^{* *}$ & $3 \cdot 4 \pm 0 \cdot 1^{* * *}$ & $41 \cdot 5 \pm 2 \cdot 0^{* * *}$ \\
& 0 & $3 \cdot 9 \pm 0 \cdot 7$ & $3 \cdot 3 \pm 0 \cdot 2$ & $31 \cdot 9 \pm 0 \cdot 7$ \\
& 5 & $7 \cdot 9 \pm 1 \cdot 4^{* *}$ & $3 \cdot 9 \pm 0 \cdot 2^{*}$ & $34 \cdot 1 \pm 1 \cdot 3^{*}$ \\
& 25 & $6 \cdot 3 \pm 0 \cdot 9^{*}$ & $3 \cdot 9 \pm 0 \cdot 2^{*}$ & $36 \cdot 0 \pm 1 \cdot 1^{* * *}$
\end{tabular}

Values are the means \pm SEM for groups of six rats and those marked with asterisks differ significantly (Student's $t$ test from the control value: ${ }^{*} P<0 \cdot 1:{ }^{* *} P<0 \cdot 05 ;{ }^{* * *} P<0 \cdot 02 ;{ }^{* * * *} P<0 \cdot 001$. 